\title{
Cost-effectiveness study of outpatient physiotherapy after medial meniscectomy
}

\author{
D P FORSTER, C E B FROST
}

\begin{abstract}
In a randomised controlled trial comparing the outcome of two groups of men aged 16-45 one group received outpatient physiotherapy after medial meniscectomy and the other did not. In clinical aspects of knee function there was no significant difference between the test group and control group measured at specified intervals up to 26 weeks postoperatively. Similarly, there was no significant difference between the groups in the time taken to return to work or in the mean fall in take-home pay as a result of meniscectomy. The mean cost per patient of providing outpatient physiotherapy in the test group was $€ 23$ at 1976 prices.

Thus the least costly way of returning male patients aged 16-45 to activity is by not providing routine outpatient physiotherapy after medial meniscectomy. Further randomised controlled trials are, however, required to determine the value of physiotherapy in other age groups and other conditions.
\end{abstract}

\section{Introduction}

In 1977 there were 12280 male admissions in England and Wales for removal of a meniscus of the knee (medial or lateral). The operation is carried out most often in young adults and is five times more common in men than in women. The annual

\footnotetext{
Medical Care Research Unit, Department of Community Medicine, University of Sheffield Medical School, Sheffield S10 2RX

D P FORSTER, MSC, MFCM, research officer (present address : Department of Family and Community Medicine, University of Newcastle upon Tyne, Newcastle upon Tyne NE1 7RU)

Division of Economics and Medical Care Research Unit, University of Sheffield, Sheffield S10 2TN

C E B FROST, BA(ECON), lecturer in economics
}

risk of admission for men in the 15-44 age group is roughly one in $1000 .^{1}$

In a randomised controlled trial Leonard ${ }^{2}$ concluded that results at six months after medial meniscectomy showed no difference between the use of a compression bandage for 10 days and a regimen in which the postoperative compression bandage was replaced by a plaster cylinder after 48 hours. The stay in hospital for patients using the "plaster regimen" was halved. Seymour, ${ }^{3}$ who used the compression bandage method, concluded in a randomised controlled trial of outpatient physiotherapy after medial meniscectomy that there was no advantage for the physiotherapy group in terms of the range of movement of the knee, quadriceps bulk, effusion into the knee joint, and time of return to work when the patients were assessed three months after the operation. He did not, however, use statistical methods in the assessment.

The aim of the current trial was to compare the outcome after meniscectomy between two randomly selected groups of patients treated by the "plaster regimen," one of which received outpatient physiotherapy and the other did not. A further aim was to assess and compare the costs to the National Health Service and to the patients.

\section{Method}

The potential subjects for the trial were consecutive patients of four consultant orthopaedic surgeons working in three Sheffield hospitals. The admission criteria to the trial were as follows: men aged from 16 to 45 years who were available for work-that is, full-time students were excluded; a clinical diagnosis of torn medial meniscus; the willingness of the patient to enter either group; and removal of the medial meniscus at operation. The eligible patients were allocated by stratified random sampling to a test group that received outpatient physiotherapy and a control group that did not. Both groups were stratified according to whether the patient's work was sedentary or active and to the hospital in which the operation was performed.

If the operation day is counted as day zero (day 0 ) a compression bandage was applied immediately after operation and replaced by a plaster on day 3 and the patient was then discharged from hospital. 
TABLE I-Comparison of groups for clinical outcome-quantitative variables

\begin{tabular}{|c|c|c|c|c|c|c|c|c|}
\hline \multirow{2}{*}{ Variable } & \multirow{2}{*}{$\begin{array}{l}\text { Time period for } \\
\text { assessment }\end{array}$} & \multicolumn{2}{|c|}{ Test } & \multicolumn{2}{|c|}{ Control } & \multirow{2}{*}{$t$ value } & \multirow{2}{*}{$\begin{array}{l}\text { Degrees of } \\
\text { freedom }\end{array}$} & \multirow{2}{*}{$\begin{array}{l}\text { Probability } \\
\text { (2 tailed) }\end{array}$} \\
\hline & & $\begin{array}{l}\text { No of } \\
\text { cases }\end{array}$ & Mean & $\begin{array}{l}\text { No of } \\
\text { cases }\end{array}$ & Mean & & & \\
\hline Quadriceps circumference & $\begin{array}{l}\text { Preoperation } \\
10 \text { days } \\
4 \text { weeks } \\
6 \text { weeks } \\
10 \text { weeks } \\
14 \text { weeks } \\
26 \text { weeks }\end{array}$ & $\begin{array}{l}44 \\
43 \\
42 \\
44 \\
41 \\
40 \\
43\end{array}$ & $\begin{array}{l}46.2 \mathrm{~cm} \\
45.3 \mathrm{~cm} \\
45.1 \mathrm{~cm} \\
45.7 \mathrm{~cm} \\
46.2 \mathrm{~cm} \\
46.5 \mathrm{~cm} \\
46.8 \mathrm{~cm}\end{array}$ & $\begin{array}{l}42 \\
41 \\
42 \\
40 \\
39 \\
41 \\
41\end{array}$ & $\begin{array}{l}46 \cdot 3 \mathrm{~cm} \\
45 \cdot 3 \mathrm{~cm} \\
44.8 \mathrm{~cm} \\
45 \cdot 3 \mathrm{~cm} \\
45 \cdot 8 \mathrm{~cm} \\
46.3 \mathrm{~cm} \\
46.3 \mathrm{~cm}\end{array}$ & $\begin{array}{r}-0.04 \\
-0.09 \\
0.31 \\
0.69 \\
0.51 \\
0.33 \\
0.79\end{array}$ & $\begin{array}{l}84 \\
82 \\
82 \\
82 \\
78 \\
79 \\
82\end{array}$ & $\begin{array}{ll}0.97 & \text { NS } \\
0.93 & \text { NS } \\
0.76 & \text { NS } \\
0.49 & \text { NS } \\
0.61 & \text { NS } \\
0.74 & \text { NS } \\
0.43 & \text { NS }\end{array}$ \\
\hline Range of knee movement & $\begin{array}{l}\text { Preoperation } \\
10 \text { days } \\
4 \text { weeks } \\
6 \text { weeks } \\
10 \text { weeks } \\
14 \text { weeks } \\
26 \text { weeks }\end{array}$ & $\begin{array}{l}43 \\
43 \\
42 \\
44 \\
41 \\
40 \\
43\end{array}$ & $\begin{array}{l}122 \cdot 3^{\circ} \\
\mathrm{N} / \mathrm{A} \\
114.5^{\circ} \\
129 \cdot 8^{\circ} \\
136 \cdot 3^{\circ} \\
139 \cdot 2^{\circ} \\
139 \cdot 6^{\circ}\end{array}$ & $\begin{array}{l}42 \\
41 \\
42 \\
40 \\
39 \\
41 \\
41\end{array}$ & $\begin{array}{l}124.3^{\circ} \\
\mathrm{N} / \mathrm{A} \\
116 \cdot 2^{\circ} \\
128.9^{\circ} \\
134.9^{\circ} \\
137.0^{\circ} \\
139.9^{\circ}\end{array}$ & $\begin{array}{r}-0.35 \\
\text { N/A } \\
-0.35 \\
0.29 \\
0.64 \\
1.29 \\
-0.16\end{array}$ & $\begin{array}{c}83 \\
\text { N/A } \\
82 \\
82 \\
78 \\
79 \\
82\end{array}$ & $\begin{array}{l}0.73 \text { NS } \\
\text { N/A } \\
0.73 \text { NS } \\
0.77 \text { NS } \\
0.52 \text { NS } \\
0.20 \text { NS } \\
0.87 \text { NS }\end{array}$ \\
\hline
\end{tabular}

TABLE II-Comparison of groups for clinical qualitative variables

\begin{tabular}{|c|c|c|c|c|c|c|}
\hline \multirow[b]{2}{*}{ Variable } & \multicolumn{3}{|c|}{ Preoperative } & \multicolumn{3}{|c|}{ 26th week assessment } \\
\hline & $\begin{array}{c}\text { Test } \\
(\mathrm{n}=44) \\
\%\end{array}$ & $\begin{array}{c}\text { Control } \\
(\mathrm{n}=42) \\
\%\end{array}$ & Probability & $\begin{array}{c}\text { Test } \\
(n=43) \\
\% \\
\%\end{array}$ & $\begin{array}{c}\text { Control } \\
(\mathrm{n}=41) \\
\%\end{array}$ & Probability \\
\hline $\begin{array}{l}\text { Effusion present } \\
\text { Knee gives way } \\
\text { Ability to crouch impaired } \\
\text { Gait impaired } \\
\text { Gait ascending impaired } \\
\text { Gait descending impaired } \\
\text { Running downstairs impaired } \\
\text { Wound not healed }\end{array}$ & $\begin{array}{l}20 \cdot 5 \\
45 \cdot 5 \\
68 \cdot 2 \\
36 \cdot 4 \\
9 \cdot 1 \\
15 \cdot 9 \\
61 \cdot 4 \\
\text { N/A }\end{array}$ & $\begin{array}{l}23 \cdot 8 \\
61.9 \\
71.4 \\
40.5 \\
4 \cdot 8 \\
14.3 \\
54 \cdot 8 \\
\text { N/A }\end{array}$ & $\begin{array}{l}0.91 \text { NS } \\
0.19 \text { NS } \\
0.93 \text { NS } \\
0.86 \text { NS } \\
0.72 \text { NS } \\
0.93 \text { NS } \\
0.69 \text { NS } \\
\text { N/A }\end{array}$ & $\begin{array}{r}6 \cdot 8 \\
15.9 \\
34 \cdot 9 \\
2 \cdot 3 \\
2 \cdot 3 \\
0 \\
4 \cdot 7 \\
0\end{array}$ & $\begin{array}{l}4 \cdot 9 \\
12 \cdot 2 \\
29 \cdot 3 \\
4 \cdot 9 \\
0 \\
0 \\
7 \cdot 3 \\
0\end{array}$ & $\begin{array}{l}0.94 \text { NS } \\
0.86 \text { NS } \\
0.75 \text { NS } \\
0.97 \text { NS } \\
0.98 \text { NS } \\
\text { N/A } \\
0.96 \text { NS } \\
\text { N/A }\end{array}$ \\
\hline
\end{tabular}

Walking without weight bearing-that is, using crutches-was allowed from days 3 to 9 . On day 10 the plaster was removed and walking was allowed with weight bearing. The test group underwent a regimen of outpatient physiotherapy-usually three visits weekly for four weeks starting on the 12th postoperative day. The regimen, however, was not fixed, since by clinical decision it could be made slightly longer or shorter. Both groups received the same inpatient physiotherapyfor example, quadriceps strengthening exercises-and both groups were also advised on how to work the quadriceps muscles in the plaster and do straight leg raising in the plaster and on exercises to carry out at home.

Before operation a standard questionnaire was completed on all subjects about the nature of injury to the knee, employment, time lost from work, sickness benefit, perquisites, earnings, and subsidiary earnings. Clinical examination of the knee was carried out in a standardised way to test certain technical aspects before operationfor instance, the range of movement as measured by a goniometerand simple functions such as the ability to run downstairs. Postoperative assessments were made at 10 days, four weeks, six weeks, 10 weeks, 14 weeks, and 26 weeks. In addition to the postoperative clinical assessments, questions were also asked on each occasion about days lost from work, fall in net pay, and other losses of earnings, and in the test group about the days lost because of physiotherapy.

Allocation to the trial, which was carried out from 1975 to 1979, was blind-that is, from sealed envelopes-but assessment was not. Assessments were made by two observers who had previously been shown to make reliable measurements on the same patients. Comparisons between quantitative variables were made using the two sample $t$-test and between qualitative variables using chi square.

\section{Results}

Of the 86 patients admitted to the trial, 44 were randomly allocated to the outpatient physiotherapy group and 42 to the control group. On the basis of clinical and non-clinical information gained before allocation, the two groups were compared on 34 variables. Five $(11.4 \%)$ of the treatment group and $12(28.6 \%)$ of the control group had had a recent injury due to sport $(p=0.05)$. This was the only significant difference between the groups. This difference was not thought to be important to the outcome of the trial, however, since there was no significant difference between the two groups with respect to a compensation claim pending. Further validation tests showed that there was no significant difference between responders and non-responders at each assessment check; no significant difference between the groups for the mean time between the date of discharge and each of the dates of the six postoperative assessment checks; and no significant difference between the groups for the development of clinical symptoms unconnected with the knee joint. One patient in the control group received specific physiotherapy after the 14th postoperative week.

Table I compares the two groups for quadriceps circumference (average of two readings at a point $10 \mathrm{~cm}$ above the upper tip of the patella) and range of knee movement (average of two readings). At each assessment point there was no significant difference between the groups on either of these quantitative variables. Table II shows a comparison of the groups preoperatively and at 26 weeks for clinical qualitative variables. At 26 weeks there were small differences between the groups for effusion (fluid could be milked into the lateral parapatellar hollow or more severe condition); knee giving way; and impairment of ability to crouch, of gait (walking with a stiff knee or more severe), of gait ascending (one leg lead or more severe), and running downstairs. None of these differences, however, was significant. In both groups the ability to descend stairs (walking) was not impaired for anybody and wound healing was complete at 26 weeks. Similarly, comparisons at four weeks, six weeks, 10 weeks, and 14 weeks did not show significant differences between the groups for clinical qualitative variables. Table III shows that there was no significant difference between the two groups in the time taken to return to work and the days lost from work since discharge from the hospital. In the test group time lost from work because of outpatient physiotherapy was included in the days lost from work. At the end of the 26-week follow-up period, four out of 44 in the test group and three out of 41 in the control group had failed to return to work. (One patient in the control group was lost to follow-up.) Each attendance at physiotherapy was counted as half a day lost from work. This gave an average of 6.2 days lost per patient in the test group-that is, a mean number of attendances of 12.4 per patient. The mean fall in

TABLE III-Comparison of test and control groups for work records

\begin{tabular}{lcccccc}
\hline \multirow{2}{*}{ Variable } & \multicolumn{2}{c}{ Mean value } & & & \\
\cline { 2 - 5 } & $\begin{array}{c}\text { Test } \\
\text { group }\end{array}$ & $\begin{array}{c}\text { Control } \\
\text { group }\end{array}$ & & $\begin{array}{c}\text { Degrees of } \\
\text { freedom }\end{array}$ & $\begin{array}{c}\text { Probability } \\
\text { (2 tail) }\end{array}$ \\
\hline $\begin{array}{c}\text { Time taken to return } \\
\text { to work }\end{array}$ & 57.7 days & 53.7 days & 0.52 & 76 & $0.60 \mathrm{NS}$ \\
$\begin{array}{c}\text { Actual days lost from } \\
\text { work }\end{array}$ & 49.4 days & 49.4 days & 0 & 79 & $1.00 \mathrm{NS}$ \\
$\begin{array}{c}\text { Days lost through } \\
\text { physiotherapy }\end{array}$ & 6.2 days & N/A & N/A & N/A & N/A \\
\hline
\end{tabular}


take-home pay in both groups as a result of the operation and subsequent procedures did not differ significantly between the two groups and was estimated as $£ 162$ (weighted mean derived from the two groups). Other possible costs to the patients were sought but these were found to be small compared with the loss of earnings. The mean cost (at 1976 prices) of providing outpatient physiotherapy to the test group was $£ 23$.

\section{Discussion}

A trial of this size will give about an $80 \%$ chance of detecting at the $5 \%$ level of significance a true difference between the groups of $30 \%$ when $50 \%$ respond to the control regimen, though there would clearly be a smaller chance of detecting true differences between the groups of less than $30 \% .^{4}$ The validation analyses show that the groups were comparable preoperatively. The regimens in the two groups were similar except that the test group received outpatient physiotherapy. The trial was testing the offer of outpatient physiotherapy and non-compliance by patients with the outpatient physiotherapy regimen was accepted as part of the real state of affairs. (In fact we know that, overall, compliance was high since a test group patient received 12.4 outpatient physiotherapy treatments on average, though there was variation between individual patients.)

Although the primary purpose of the trial was not to test the benefits of medial meniscectomy per se, the results indicate considerable improvements in both groups on all clinical measurements except quadriceps circumference between the preoperative measurements and assessment at 26 weeks. In fact the differences between the groups were small and not significant compared with the changes in both groups over the period. Moreover, there was no significant advantage to the test group in terms of quicker return to work or a reduction in lost earnings. Hence we would argue that there is no proved case in favour of routine outpatient physiotherapy after medial meniscectomy in men of this age, though patients should continue to receive instructions about exercises to practise at home and also, possibly, physiotherapy as an inpatient. Although men in this age range receive about $67 \%$ of all knee cartilage operations, we would not extrapolate our results to other age groups or to other conditions since the men considered were generally fit and free from other illness.

We would suggest that the resources saved by discontinuing routine outpatient physiotherapy after meniscectomy for men in this category ( $£ 23$ average cost per course of treatment at 1976 prices) could be diverted to the physiotherapy of conditions in which benefit might accrue. Nevertheless, although Partridge and Warren ${ }^{5}$ have noted several randomised controlled trials in physiotherapy, it remains a relatively under-researched discipline. Our interim conclusion must be that further randomised controlled trials are required in other areas of physiotherapy.

We are grateful to the DHSS for a grant for this study. The Medical Care Research Unit is also supported by Trent RHA. We are particularly grateful to Mrs A Swindells for the physiotherapy assessments; to $\mathrm{Mr} \mathrm{T}$ McDonald and others for physiotherapy treatments; to Mr D K Evans, Mr W J W Sharrand, Mr T W D Smith, and Professor T Duckworth for allowing their patients to enter the trial; to Mrs J Gyte for coding; and to Mr J Bradley, Professor J Knowelden, and the DHSS for advice.

\section{References}

${ }^{1}$ DHSS, OPCS, Welsh Office. Hospital inpatient enquiry for 1977. Series MB4 No 10. London: HMSO, 1980.

${ }^{2}$ Leonard MA. An evaluation of two post-meniscectomy regimes. Health Bulletin 1973;31:193-4.

${ }^{3}$ Seymour $\mathrm{N}$. The effectiveness of physiotherapy after medial meniscectomy. Br F Surg 1969;56:518-20.

4 Clark CJ, Downie CC. A method for the rapid determination of the number of patients to include in a controlled clinical trial. Lancet 1966 ;ii :1357-8.

${ }^{5}$ Partridge CJ, Warren MD. Physiotherapy in the community. Canterbury: Health Services Research Unit, University of Kent, 1977.

(Accepted 7 December 1981)

\section{MEDICINE AND THE MEDIA}

PIONEERS in any endeavour are fascinating characters. Two television documentaries recently examined the contemporary vanguard of researchers on in vitro fertilisation, who on the whole emerged with their public image still glowing. The Test Tube Explosion (ITV, 2 February)-the first networked programme from the independent company TVScontained exclusive interviews with $\mathrm{Mr}$ Patrick Steptoe, Dr Robert Edwards, and patients at their private clinic. (Curiously old-fashioned, these pioneers: Edwards, the scientist, suggested that Bourne Hall's stately ambience might be an aid to fertility, as might the patient's determination.) A month previously, Panorama's Experimenting with Life (BBC1, 21 December) had had to be content with a passing reference to Steptoe and Edwards's "exclusive estate" and instead had interviewed Professor Ian Craft of London and Professor Carl Wood of Melbourne-the latter impressively articulate on the ethical as well as the medical aspects of his work.

Both programmes were well researched and clearly presented and inevitably had similarities. Both briefly referred to hysterical public reaction to fertilisation work in the United States. Using superb pictures, both effectively conveyed the excitement of basic research at the very frontiers of knowledge. Both led the viewer from cosy pictures of avuncular consultants giving joy to childless couples, through the complexities of reproductive physiology into a nightmare future of human clones, genetic engineering, and embryos grown for research. Pictures of cloned mice on BBC and (more striking) cloned sheep on ITV emphasised that this brave new world is no science fiction.
Peter Williams, the TVS producer, left the sweeter after-taste by emphasising the human interest: the doctors were clearly people of integrity and the patients (who remarked, accurately, that they knew more about the subject than most doctors) were indignant or sceptical at the idea that such research should be stopped. This suggestion had come from Dr Michael Thomas, chairman of the BMA Central Ethical Committee, but his objections sounded unconvincing in the context of the TVS programme. By contrast, Panorama's Margaret Jay emphasised the ethical problems from the outset, using interviews with doctors and lawyers who see legal and moral complexity ahead. Panorama, concerned without being alarmist, suggested that our generation's technical cleverness may not be matched by its legislative farsightedness-an accusation that has an uncomfortable ring of truth.

Both programmes, despite their differences, informed and involved the viewer as only television can. It is difficult to depict in printed words the self-destructive urge towards reproduction that takes over the lives of some infertile women, but the inappropriateness of Dr Thomas's word "whim" needed no underlining once we had met the fiercely determined couples concerned. There was the occasional whiff of the ridiculous: Landrum B Shettles's clinic in Sunset Strip, Las Vegas; Edwards' hasty dash from Petri dish to patient; or the doctor who held the patient's hand and said, "We've got a beautiful egg." Television was also able to demonstrate the streak of naivete that seems to be a necessary part of a medical pioneer's character: now and again an eminent doctor or scientist appeared to be thinking about an ethical problem for the first time as the cameras rolled.-JAMES OWEN DRIFE, lecturer in gynaecology, Bristol. 